\title{
Pengembangan Reading Domino sebagai Media Belajar Membaca Bahasa Inggris Anak Usia 5-6 Tahun
}

\author{
Dian Erilya Batmanlusy, Mozes Kurniawan ${ }^{\bowtie}$ \\ Pendidikan Guru Anak Usia Dini, Universitas Kristen Satya Wacana \\ DOI: $10.31004 /$ obsesi.v5i1.615
}

\begin{abstract}
Abstrak
Penelitian ini bertujuan untuk mengembangkan media reading domino sebagai media belajar membaca bahasa Inggris pada anak usia dini 5-6 tahun. Penelitian ini termasuk jenis penelitian dan pengembangan yang mengembangkan media reading domino yang berisi materi media belajar membaca bahasa Inggris bagi anak.Subjek penelitian dalam penelitian ini adalah 44 anak TK B Lab Kristen Satya Wacana.Teknik pengumpulan data dilakukan dengan observasi dan wawancara untuk mendapatkan informasi.Data dianalisis secara deskriptif kuantitatif dan kualitatif. Hasil penelitian menunjukkan bahwa, pada uji validitas media reading domino sebagai media belajar membaca bahasa Inggris pada anak usia 5-6 tahun termasuk dalam kategori "sesuai" dan uji validitas media untuk materi termasuk dalam kategori "sangat sesuai" dengan sedikit perbaikan yang dilakukan dalam tahap revisi. Dengan demikian, media reading domino sebagai media belajar membaca bahasa Inggris dapat digunakan untuk tahap selanjudnya yaitu tahap uji coba produk.
\end{abstract}

Kata Kunci: pengembangan media; belajar membaca bahasa inggris, anak usia dini.

\begin{abstract}
This study aims to develop Reading Domino as a learning media for reading English in early childhood 5-6 years. This is a research and development which developed media to reading English for children. The research subjects in this study were TK B Lab Kristen Satya Wacana students. Data collection techniques are done by observation and interviews to obtain information. Data were analyzed descriptively quantitative and qualitative. The results showed that, in the test of the validity of domino reading media as a medium of learning to read English in children aged 5-6 years included in the category "appropriate" with a slight and the test of media validity for the material included in the category of "very appropriate "With a few improvements made in the revision stage. Thus, Reading Dominoas a media for learning to reading English can be used for the next stage which is the product trial step.
\end{abstract}

Keywords : media develompent: reading english learning; early childhood.

Copyright (c) 2020 Dian Erilya Batmanlusy, Mozes Kurniawan

$\triangle$ Corresponding author :

Email Address : mozeskurniawan@uksw.edu ( Salatiga, Indonesia )

Received 24 June 2020, Accepted 17 July 2020, Published 10 August 2020 


\section{PENDAHULUAN}

Perkembangan bahasa pada anak usia dini merupakan salah satu faktor yang mempengaruhi perkembangan kognitif anak (Pebriana, 2017). Periode paling sensitif terhadap bahasa dalam kehidupan seseorang adalah antara usia 0-8 tahun. Pada periode sensitif ini sangat penting diperkenalkan cara berbahasa yang baik dan benar karena keahlian ini sangat berguna untuk berkomunikasi dengan lingkungannya Bahasa anak akan muncul dan berkembang melalui berbagai situasi interaksi sosial dengan orang dewasa (Suciati, 2018). Peranan bahasa bagi AUD diantaranya sebagai sarana untuk berpikir, mendengarkan, berbicara dan untuk kemampuan membaca dan menulis. Disamping itu untuk menjalin hubungan manusia dengan manusia lainnya, dibutuhkan bahasa sebagai alat komunikasi (Yumi et al., 2019). Dalam masa perkembangan, tingkat pencapaian bahasa anak usia 5-6 tahun menurut(Sulaiman et al., 2019): kemampuan berbahasa merupakan kesanggupan, kecakapan, kekayaan, ucapan pikiran dan perasaan manusia melalui bunyi yang digunakan untuk bekerjasama, berinteraksi, dan mengidentifikasi diri dalam percakapan yang baik (Muzaiyanah, 2015).

Anak mempelajari bahasa dengan berbagai cara, yakni: meniru, menyimak, mengekspresikan, dan juga bermain. Melalui bermain, anak dapat belajar menggunakan bahasa secara tepat dan belajar mengkomunikasikannya secara efektif dengan orang lain.. Dalam konteks perkembangan bahasa ada beberapa bagian yaitu mendengarkan, berbicara, membaca, dan menulis dini. Belajar membaca AUD terdiri dari beberapa komponen. Budihastimenyebutkan beberapa komponen membaca, yaitu: (a) pengenalan kata-kata, pengenalan persamaan antara apa yang diucapkan dan apa yang ditulis sebagai simbol; (b) pengertian, mengenali simbol dan dapat mengucapkan, dalam membaca yang terpenting adalah mengerti mengerti apa yang dibaca; (c) reaksi, terhadap hal yang dibaca; dan (d) penggabungan, asimilasi ide-ide yang diharapkan dari mereka dengan pengalaman membaca dimasa lalu (Rahman, 2009).

Berdasarkan hasil observasi awal di TK B Kristen Satya Wacana, minggu pertama pembelajaran bahasa Inggris berlangsung hanya mengenalkan dua kosa kata kepada anak dengan cara mengucapkan kepada anak, kemudian anak hanya mengikuti yang diucapkan guru. Pada saat itu guru memperkenalkan kata "short" dan "tall" menggunakan media yang terbatas. Guru menggunakan spidol dan sedotan sebagai contoh media. Setelah itu anakanak membuat lingkaran besar dan sambil bernyanyi guru memberikan aba-aba meneriakan "tall" berarti anak akan berdiri dan jika "short" berarti anak akan duduk. Dalam permainan tersebut ada anak yang sudah paham,akan tetapi ada beberapa anak yang masih salah atau bingung dengan aba-aba yang diberikan karena anak tersebut belum memahami tentang dua kosa kata tersebut (Khairani, 2016).

Minggu kedua menggunakan tema "Tanah Airku".Anak diperkenalkan bendera Negara Indonesia yang berwarna "Red" dan "White". Setelah dijelaskan beberapa saat, anak diminta untuk mewarnai gambar bendera tersebut menggunakan crayon. Pada minggu ketiga pembelajaran anak diperkenalkan dengan lambang Negara Indonesia, presiden dan wakil presiden. Setelah itu anak diminta untuk menempel gambar lambang Negara Indonesia yaitu garuda pada tulisan yang sudah ada di kertas dan selanjutnya gambar presiden dan wakil presiden serta gambar bendera Negara Indonesia.

Dari hasil observasi ini masalah yang muncul adalah anak tidak secara langsung belajar membaca atau mengeja atau pengenalan huruf atau simbol melainkan anak mengikuti ucapan guru kemudian diberikan tugas. Oleh sebab itu pembelajaran bahasa Inggris yang menarik adalah dengan bantuan permainan atau penggunaan media pembelajaran kreatif untuk mengatasi kebosanan atau kejenuhan anak di dalam kelas yang senantiasa berubah-ubah. Permasalahan tersebut memerlukan pemecahan yang memperbaiki kemampuan membaca permulaan dengan kegiatan yang lebih menarik dan pembelajaran yang dikemas menggunakan prinsip bermain sambil belajar. Penggunaan 
media pembelajaran dalam kegiatan belajar mengajar akan membantu menarik minat anak untuk belajar.

Seperti yang kita ketahui, media pembelajaran sangatlah berperan penting dalam proses pembelajaran. Namun, pada kenyataannya media yang digunakan yaitu: media yang digunakan hanya berupa buku majalah untuk menebalkan huruf, terbatasnya media yang tersedia di sekolah, dan media yang ada tidak digunakan secara maksimal. Reading Domino merupakan permainan yang merupakan suatu permainan untuk memicu aspek dalam perkembangan anak usia dini, salah satunya yaitu aspek bahasa. Reading Domino ini didesain khusus untuk AUD terutama usia 5-6 tahun melalui permainan tersebut anak merasa senang, merasa tidak dibatasi atau dipaksakan pada saat pembelajaran dan melakukan kegiatan permainan tersebut.

Reading Domino ini setiap sisi sebelah kanan, kiri, atas dan bawah memiliki 7 kotak dan total keseluruhan ada 49 kotak. Bagian kartu terdapat gambar dan nama gambar sehingga anak akan menghubungkan gambar beserta nama dengan benar seperti pada umumnya kita memainkan kartu domino.Alasan peneliti mengembangkan media pembelajaran Reading Domino untuk meningkatkan kemampuan membaca anak usia dini adalah ketertarikan peserta didik terhadap media yang memiliki tampilan berupa gambar dan media pembelajaran Reading Domino belum pernah digunakan pada proses pembelajaran sebelumnya dan Reading Domino adalah produk baru. Kelebihan dari media Reading Domino sendiri adalah sebagai media yang dapat membantu anak untuk belajar bahasa Inggris dengan sangat mudah dan saling komperatif serta komunikatif antara teman satu dengan teman yang lain.

Dengan demikian peneliti tertarik untuk mengembangkan suatu produk pembelajaranyang baru yaitu "Reading Domino". Dengan mempertimbangkan usia anak yang masih kanak-kanak, maka media ini diharapkan untuk memudahkan anak dimulai dari hal-hal kecilyang memicu aspek dalam perkembangan anak usia dini. Reading Domino ini didesain khusus untuk anak agar anak tertarik dan tertantang di dalam permainan tersebut pada saat proses pembelajaran membaca bahasa Inggris. Diharapkan pengembangan media ini sebagai sarana yang dapat membuat anak lebih menyenangkan dan memudahkan anak dalam belajar (Hotimah, 2010).

Adapun rumusan masalah dalam penelitian ini yaitu bagaimana proses pengembangan media Reading Domino dalam meningkatkan keterampilan membaca permulaan bahasa Inggris pada anak usia 5-6 tahun di TK Kristen Satya Wacana? Dengan tujuan penelitian yaitu untuk mengembangkan media Reading Domino sebagai alat untuk meningkatkan membaca bahasa Inggris pada anak usia 5-6 tahun di TK Kristen Satya Wacana.

\section{METODOLOGI}

Penelitian yang dilakukan menggunakan metode penelitian dan pengembangan atau Research and Developmentyang bertujuan untuk mengembangkan produk berdasarkan uji coba untuk kemudian diperbaiki hingga menghasilkan produk yang layak pakai. Produk yang akan dikembangkan adalah media papan permainanReading Domino.Penelitian yang telah dilakukan pada tanggal 5 Agustus 2019 sampai 23 Agustus 2019. Subjek yang dimaksud pada penelitian ini yakni media pembelajaran Reading Domino yang akan diteliti kelayakan Reading Domino untuk meningkatkan kemampuan membaca anak.

Prosedur pengembangan yang digunakan menurut teori Borg dan Gall yang terdiri dari sepuluh tahap. Berdasarkan tahapan penelitian dan pengembangan yang dikembangkan, peneliti melakukan penyederhanaan dan pembatasan menjadi lima tahapan, penyerdahanaan dilakukan karena beberapa faktor yakni keterbatasan waktu penelitian dan keterbatasan data. Ada pun tahanp-tahap penelitian yang ditempuh yaitu(Sugiyono, 2012): 
(a) potensi dan masalah; (b) pengumpulan data; (c) desain produk; (d) validasi desain oleh ahli materi dan ahli media; dan (e) revisi desain (lihat Gambar 1).

Pengumpulan data dalam penelitian ini yaitu dilakukan dengan pengisian angket, wawancara, dan dokumentasi. Instrumen penelitian menggunakan skala Likert yang disusun dalam bentuk checklist dengan skor maksimum yang diinginkan yaitu 5 yang terdiri dari: (1) SS: sangat sesuai, (2) S: sesuai, (3) KS: kurang sesuai, (4) TS: tidak sesuai, dan (5) STS : sangat tidak sesuai. Kisi-kisi angket validasi ahli materi dan ahli media pada Tabel 1.

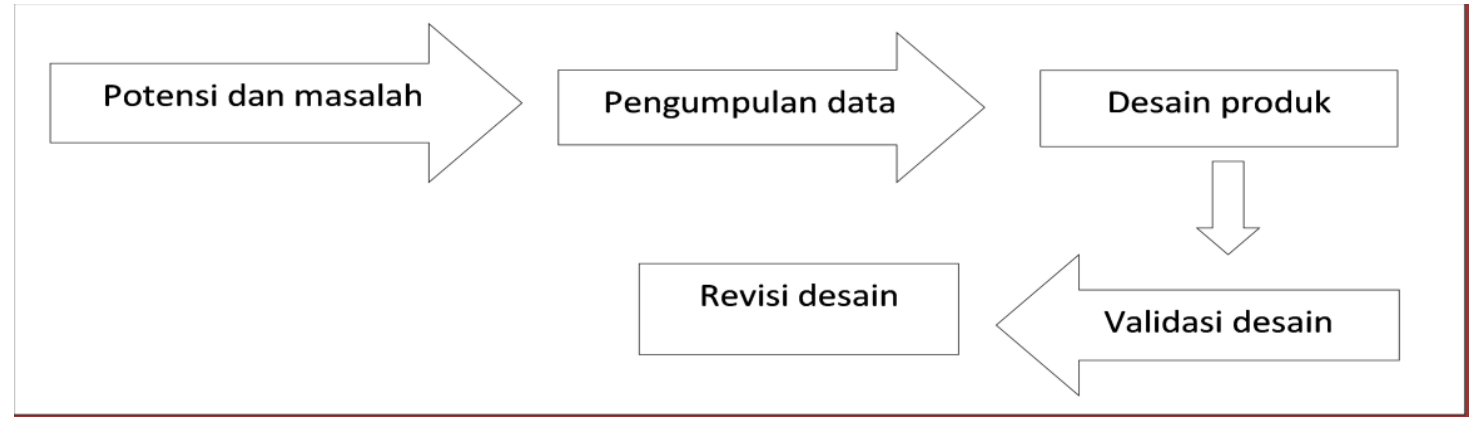

Gambar 1. Langkah-Langkah Penelitian dan Pengembangan

Teknik analisis data yang digunakan dalam penelitian ini adalah analisis deskriptif yang digunakan untuk menganalisa data dengan cara mendeskripsikan atau menggambarkan data yang telah terkumpul sebagaimana adanya tanpa bermaksud membuat kesimpulan yang berlaku untuk umum atau generalisasi (Sugiyono, 2012). Setelah data terkumpul, maka dilakukan perhitungan skor rata-rata dengan rumus:
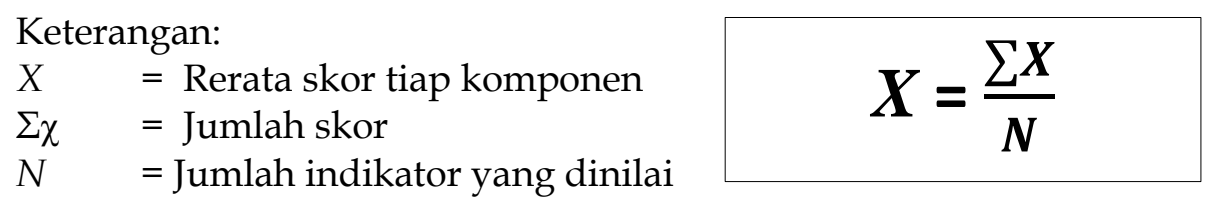

Data kuantitatif yang diperoleh dari angket kemudian dianalisis dengan teknik analisis deskriptif dengan menggunakan skala lima yang dikemukakan oleh Sukardjo dalam jurnal yang ditulis Wahyu Adi (Mawarni et al., 2015). Data berupa skor penilaian dari ahli media dan ahli materi yang diperoleh dari angket diubah menjadi data interval. Di dalam angket disediakan lima pilihan untuk memberikan tanggapan terhadap kualitas produk yang dikembangkan, yaitu: Sangat Sesuai bernilai 5, Sesuai bernilai 4, Kurang Sesuai bernilai 3, Tidak Sesuai bernilai 2, dan Sangat Tidak Sesuai bernilai 1. Skor dihitung dan dijumlahkan kemudian dikonversikan menjadi data kualitatif dengan skala lima (lihat Tabel 1).

Tabel 1.Pedoman Hasil Konversi Data Kuantitatif Ke Data Kualitatif

\begin{tabular}{ccc}
\hline Skor & Rentang & Kriteria \\
\hline $\mathbf{5}$ & $X>4,08$ & Sangat Sesuai \\
\hline $\mathbf{4}$ & $3,36<X \leq 4,08$ & Sesuai \\
\hline $\mathbf{3}$ & $2,64<X \leq 3,36$ & Kurang Sesuai \\
\hline $\mathbf{2}$ & $1,92<X \leq 2,64$ & Tidak Sesuai \\
\hline $\mathbf{1}$ & $X \leq 1,92$ & Sangat Tidak Sesuai \\
\hline
\end{tabular}




\section{HASIL DAN PEMBAHASAN}

Dalam mempelajari bahasa, Bahasa Inggris merupakan bahasa asing yang harus diberikan kepada anak usia dini karena bahasa Inggris di zaman sekarang sangatlah penting (Widiarina, 2016). Keberhasilan pembelajaran bahasa Inggris pada anak usia dini sangat dipengaruhi oleh kemampuan guru dalam menyajikan proses kegiatan belajar mengajar yang menarik dan menyenangkan bagi anak. Banyak metode dan teknik yang dapat digunakan untuk mengajar bahasa Inggris, diantaranya melalui: (a) story telling (bercerita); (b) role play (bermain peran); (c) art and crafts (seni dan kerajinan tangan); (d) games (permainan); (e) show and tell; dan (e) music and movement (gerak dan lagu). Tentunya persiapan yang kreatif dalam menerapkan metode pembelajaran diperlukan dalam pembelajaran bahasa Inggris (Kurniawan, 2020).

Pembelajaran bahasa Inggris pada AUD hanya sebatas pengenalan dan dasardasarnya saja.Pendidik diharapkan mengajarkan hal-hal yang sangat dasar terlebih dahulu, misalnya huruf-huruf abjad bahasa Inggris, angka, dan macam-macam buah-buahan, macam-macam hewan, dan sedikit percakapan yang mudah seperti:"Good morning", "How are you?", dan lain-lain). Penting untuk mengerti porsi pembelajaran bahasa Inggris bagi anak agar tidak menimbulkan gangguan/interferensi (Kurniawan, 2018).

Pembelajaran membaca bahasa Inggris jika menggunakan media permainan dan teknologi yang mutakhir akan lebih menyenangkan dibandingkan hanya menggunakan metode ceramah yang dapat membuat suasana belajar yang membuat anak menjadi bosan. Penelitian-penelitian lain telah membuktikan bahwa pengembangan permainan dalam pembelajaran bahasa Inggris meningkatkan kemampuan anak dalam membaca (Hadini, 2017). Seperti pada penelitian Astien Lilyana (2019) Speaking Pyramid sebagai Media Pembelajaran Kosa Kata Bahasa Inggris Anak Usia 5-6 Tahun menunjukan bahwa media speaking pyramid yang dikembangkan sesuai untuk diterapkan dalam uji coba sebagai alat untuk meningkatkan kosa kata bahasa Inggris anak usia 5-6 tahun di TK Kaniasius Jimbaran(Liyana \& Kurniawan, 2019) menunjukan bahwa media speaking pyramid yang dikembangkan sesuai untuk diterapkan dalam uji sebagai alat untuk meningkatkan kosa kata bahasa Inggris anak usia 5-6 tahun di TK Kanisisus Jimbaran berdasarkan hasil validasi yang dilakukan ahli materi dan ahli media dengan skor masing-masing $(4,15)$ dan $(3,6)$ yang termasuk kategori "sangat sesuai" dan "sesuai". Dengan demikian, kualitas media tidak hanya valid berdasarkan penelitian ahli materi dan ahli media, tetapi juga valid berdasarkan analisis faktor sehingga dapat terus dikembangkan lebih lanjut dan secara kualitas dapat digunakan dalam lingkup yang lebih luas. Selanjutnya dalam penelitian Nurlela (2018) tentang "Pengembangan Media Pembelajaran Busy Book dalam Meningkatkan Kemampuan Bahasa Anak Usia Dini di Play Group Islam Bina Balita Way Halim Bandar Lampung" menyimpulkan bahwa Busy Book sebagai media pembelajaran dalam meningkatkan perrkembangan bahasa anak usia dini. Busy Book dibuat dengan bahan dasar kain flannel yang berisi tentang tema alat transportasi yang tersedia gambar-gambar alat transportasi baik transportasi darat, laut, dan udara. Rata-rata penilaian validator ahli materi mendapatkan persentase kelayakan sebesar $82,6 \%$ sehingga penilaian yang dicapai validator ahli materi mendapatkan kategori "sangat layak", sedangkan rata-rata penilaian validator ahli media mendapatkan mendapatkan persentase kelayakan sebesar $85 \%$ sehingga penilaian yang dicapai validator ahli media mendapatkan kategori "sangat layak".(Mufliharsi, 2017).

Maka dengan ini, peneliti melakukan penelitian secara langsung. Berdasarkan hasil observasi dan wawancara yang diperoleh menunjukkan bahwa sudah ada penerapan kegiatan pembelajaran bahasa Inggris untuk kelompok usia 5-6 tahun di TK Lab Kristen Satya Wacana dengan jumlah siswa 44 anak, sudah diterapkan kegiatan yang berkaitan dengan bahasa Inggris baik dalam komunikasi antara guru dan anak ataupun dalam kegiatan pembelajaran.Pembelajaran bahasa Inggris dilakukan setiap hari Senin. Dalam 
kegiatan pembelajaran sesuai dengan hasil observasi yang saya lakukan, anak masih belum memahami yang disampakan guru sehingga guru harus menerjemahkan dalam bahasa Indonesia. Guru memperkenalkan kosa kata dengan mengucapkan kata kemudian anak menirukan. Salah satunya adalah Bendera Negara Indonesia berwarna merah dan putih atau dalam bahasa Inggrisnya adalah "red" dan "white". Guru melakukan pengulangan sebanyak tiga kali kemudian anak diberikan kertas yang ada gambar bendera dan anak diminta untuk mewarnainya. Oleh sebab itu untuk konsep pengenalan kosa kata anak belum dapat memahami dengan baik (Khairani, 2016)..

Dari penjelasan tersebut, peneliti tertarik untuk membuat suatu permainan yang mengembangkan kemampuan bahasa Inggris anak yang berkaitan dengan membaca, karena membaca adalah dasar untuk mempelajari atau mengembangkan suatu bahasa. Dari permasalahan tersebut maka peneliti membuat sebuah media pembelajaran menggunakan media Reading Domino untuk memecahkan suatu masalah di sekolah tersebut untuk meningkatkan kemampuan membaca bahasa Inggris (Hotimah, 2010).

Penelitian ini merupakan jenis penelitian dan pengembangan (research and development). Hasil penelitian dan pengembangan ini adalah produk media Reading Domino sebagai alat untuk meningkatkan kemampuan membaca bahasa Inggris pada anak usia 5-6 tahun. Penelitian dan pengembangan ini dilaksanakan dengan mengacu pada tahapan penelitian dan pengembangan menurut Borg dan Gall dalam (Sugiyono, 2012)) yang memaparkan ada sepuluh tahap dalam penelitian pengembangan. Kesepuluh langkah tersebut dibatasi menjadi lima tahap. Adapun faktor-faktor yang mendasari pembatasan tersebut yaitu: (a) keterbatasan waktu, waktu dan proses yang ditempuh dalam melakukan penelitian dan pengembangan dengan sepuluh tahapan relatif panjang dan lama. Oleh karena itu, melalui pembatasan tahapan penelitian dan pengembangan ini dimaksudkan untuk meningkatkan hasil penelitian yang lebih akurat sehingga nantinya dapat dilanjutkan ke tahapan selanjutnya berdasarkan data yang lebih valid; (b) keterbatasan biaya, penelitian dan pengembangan ini memerlukan biaya yang relatif besar jika dilakukan dalam sepuluh tahap sekaligus. Oleh sebab itu, diperlukan pembagian pembatasan tahapan yang disesuaikan dengan jumlah biaya yang dapat dijangkau pada saat ini.; (c) pendapat Borg \& Gall menyarankan untuk membatasi penelitian dan pengembangan dalam skala kecil termasuk langkah penelitian dalam penelitian tesis dan disertasi(Sugiyono, 2012). Kelima tahap penelitian dan pengembangan ini meliputi: (a) potensi dan masalah; (b) pengumpulan informasi; (c) desain produk; (d) validasi desain; dan (e) revisi desain. Tahap potensi dan masalah dilakukan untuk mengetahui berbagai permasalahan yang dialami anak pada kosa kata bahasa Inggris pada anak usia 5-6 tahun. Setelahnya, dilakukan pengumpulan informasi yang berkaitan dengan permasalah yang dialami anak untuk dikaji dan diberikan solusi yang dikembangkan berupa media Reading Domino. Kemudian, desain produk dibuat berdasarkan alur pembuatan desain produk yang ditetapkan. Pada tahap ini juga dipersiapkan kisi-kisi instrumen penelitian dengan berpedoman pada kriteria menurut Walker dan Hess.

\section{Rancangan Desain Awal Produk}

Rancangan peta kompetensi media Reading Domino yang dibuat berdasarkan (KEMEDIKBUD, 2013) tentang Indikator Pencapaian Perkembangan Anak Usia Lahir - 6

Tahun (lihat Tabel 1). Dari peta kompetensi kemudian dikembangkan rancangan peta materi (lihat Tabel 2). Kemudian, dibuat garis besar isi media yang didasarkan pada peta materi yang dibuat sebelumnya (lihat Tabel 3), hingga dibuat naskah media (lihat Tabel 4). 
Tabel 1. Peta Kompetensi Pemahaman Bahasa Usia 5-6 Tahun

\begin{tabular}{ll}
\hline \multicolumn{1}{c}{ Kompetensi Dasar } & \multicolumn{1}{c}{ Indikator } \\
\hline $\begin{array}{l}\text { Memahami bahasa reseptif (menyimak dan } \\
\text { membaca) }\end{array}$ & $\begin{array}{l}\text { Menceritakan kembali apa yang didengar dengan } \\
\text { kosakata yang lebih }\end{array}$ \\
\hline $\begin{array}{l}\text { Menunjukkan kemampuan berbahasa reseptif } \\
\text { (menyimak dan membaca) }\end{array}$ & $\begin{array}{l}\text { Melaksanakan perintah yang lebih kompleks } \\
\text { sesuai dengan aturan yang disampaikan (misal: } \\
\text { aturan untuk melakukan kegiatan memasak ikan) }\end{array}$ \\
\hline $\begin{array}{l}\text { Memahami bahasa ekspresif (mengungkapkan } \\
\text { bahasa secara verbal dan non verbal) }\end{array}$ & $\begin{array}{l}\text { Pendapat dengan kalimat sederhana dalam } \\
\text { berkomunikasi dengan anak atau orang dewasa }\end{array}$ \\
\hline $\begin{array}{l}\text { Menunjukkan kemampuan berbahasa ekspresif } \\
\text { (mengungkapkan bahasa secara verbal dan non } \\
\text { verbal) }\end{array}$ & $\begin{array}{l}\text { Menunjukkan perilaku senang membaca buku } \\
\text { terhadap buku-buku yang dikenali }\end{array}$ \\
\hline
\end{tabular}

Tabel 2.Peta Materi

\begin{tabular}{|c|c|c|}
\hline Materi Pokok & Isi Materi & Penjabaran Materi \\
\hline $\begin{array}{lcc}\text { Memahami } & \text { bahasa } & \text { reseptif } \\
\text { (menyimak dan membaca) } & \end{array}$ & $\begin{array}{ll}\text { - } & \text { Mengenal } \\
\text { - } & \text { Menirukan } \\
\text { - } & \text { Menyebutkan }\end{array}$ & $\begin{array}{l}\text { Jenis-jenis gambar dan kosa kata bahasa } \\
\text { Inggris yang diterapkan secara sederhana } \\
\text { seperti nama buah, sayur dan sebagainya. }\end{array}$ \\
\hline $\begin{array}{l}\text { Menunjukkan kemampuan } \\
\text { berbahasa reseptif (menyimak dan } \\
\text { membaca) }\end{array}$ & $\begin{array}{ll}\text { - } & \text { Mengenal } \\
\text { - } & \text { Menirukan } \\
\text { - } & \text { Menyebutkan }\end{array}$ & $\begin{array}{l}\text { Jenis-jenis gambar dan kosa kata bahasa } \\
\text { Inggris yang dapat dilakukan yaitu } \\
\text { menyebutkan atau menebak kosa kata } \\
\text { bahasa Inggris seperti nama benda }\end{array}$ \\
\hline $\begin{array}{l}\text { Memahami bahasa ekspresif } \\
\text { (mengungkapkan bahasa secara } \\
\text { verbal dan non verbal) }\end{array}$ & Mengungkapkan & $\begin{array}{l}\text { Anak dapat mengungkapkan apa yang } \\
\text { disampaikan oleh guru }\end{array}$ \\
\hline $\begin{array}{lr}\text { Menunjukkan } & \text { kemampuan } \\
\text { berbahasa } & \text { ekspresif } \\
\text { (mengungkapkan bahasa } & \text { secara } \\
\text { verbal dan non verbal) }\end{array}$ & Mengungkapkan & $\begin{array}{l}\text { Anak dapat menebak atau } \\
\text { mengungkapkan apa yang ada dibalik } \\
\text { kartu kosa kata bahasa Inggris }\end{array}$ \\
\hline
\end{tabular}

Selanjutnya dibuat buku petunjuk penggunaan media Reading Domino dibuat untuk memudahkan guru menggunakan media untuk meningkatkan kosa kata bahasa Inggris pada anak secara sederhana. Selain itu buku petunjuk penggunan diperuntukkan bagi guru untuk meminimalisir kesalahan penggunaan pada saat menggunakan media (Rahayu \& Fujiati, 2018). Adapun buku petunjuk penggunaan media Reading Domino secara garis besar berisi: (a) panduan awal, yang berisikan gambaran secara umum permainan; (b) pengenalan bagian-bagian dari permainan; (c) cara-cara bermain; (d) aturan dalam bermain; dan (e) cara merawat media (Elfiadi, 2016).

\section{Tabel 3. Garis Besar Isi Media Reading Domino}

\begin{tabular}{|c|c|}
\hline Judul & Reading Domino \\
\hline Materi pokok & Meningkatkan kemampuan membaca bahasa Inggris anak \\
\hline Indikator Turunan & $\begin{array}{l}\text { 1. Mampu mengenal kosa kata bahasa Inggris secara sederhana } \\
\text { 2. Mampu mengingat kosa kata bahasa Inggris } \\
\text { 3. Mampu menyebutkan kosa kata bahasa Inggris } \\
\text { 4. Mampu memperagakan kosa kata bahasa Inggris }\end{array}$ \\
\hline Format Media & $\begin{array}{l}\text { 1. Judul media "Reading Domino" } \\
\text { 2. Kartu kosa kata bahasa Inggris } \\
\text { 3. Kartu gambar } \\
\text { 4. Papan kotak persegi }\end{array}$ \\
\hline
\end{tabular}




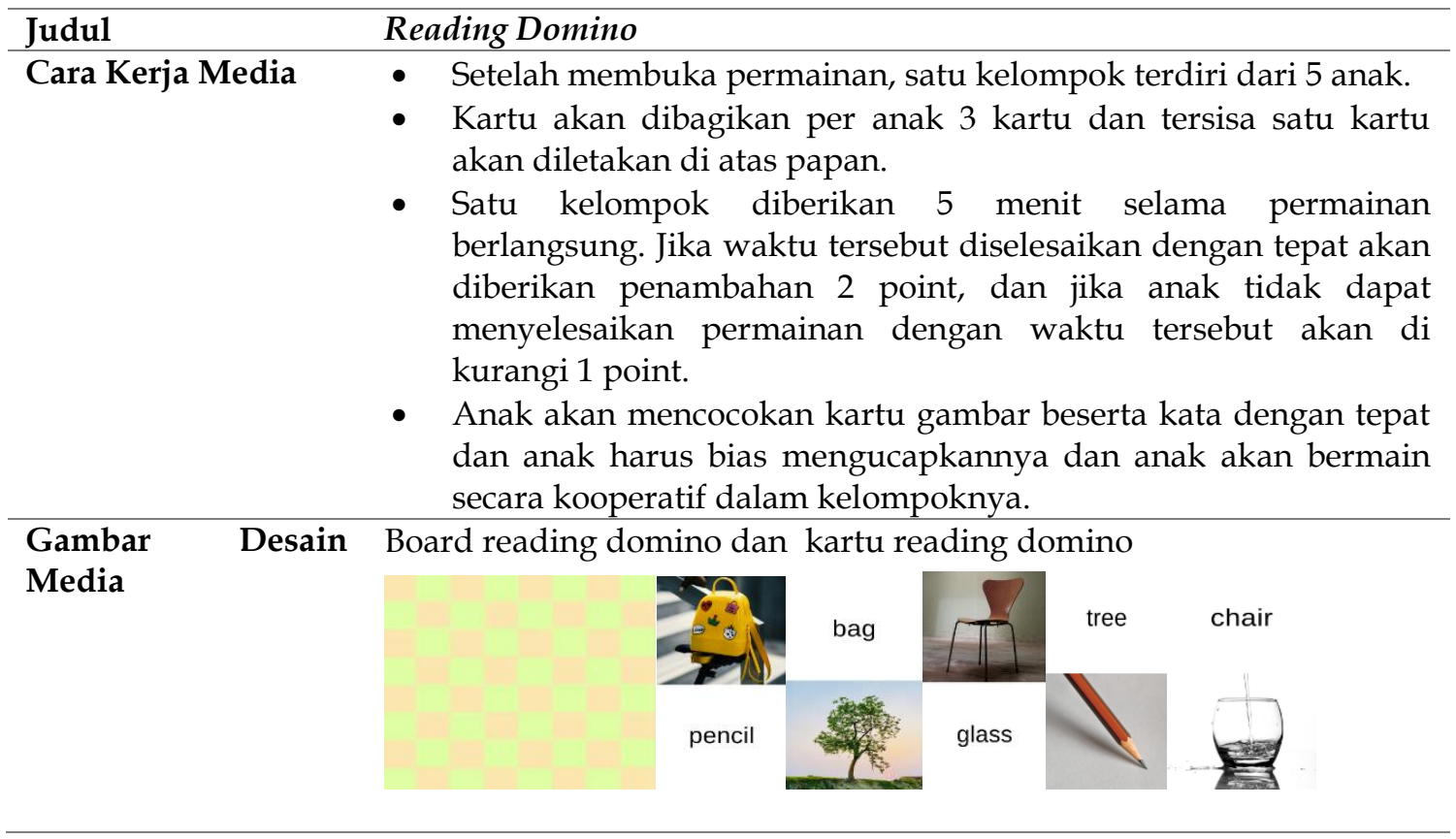

Tabel 4. Naskah Media Reading Domino

\begin{tabular}{|l|l|}
\hline \multicolumn{1}{|c|}{ Visual } & \multicolumn{1}{c|}{ Treatment } \\
\hline Jumlah Kotak & $\begin{array}{l}\text { Setiap sisi sebelah kanan dan kiri mimiliki 7 kotak, dan sisi atas, } \\
\text { bawah memiliki } 7 \text { kotak. Total keseluruhan ada } 49 \text { kotak dengan } \\
\text { ukuran } 28 \times 28 \mathrm{~cm} .\end{array}$ \\
\hline Kotak tiap sisi sudut & Kotak tiap sisi sudut adalah alur awal bermain. \\
\hline Inggris dan gambar & $\begin{array}{l}\text { Kartu yang akan dimainkan anak untuk membaca kosa kata } \\
\text { bahasa Inggris. Dengan jumlah kartu 16 buah. }\end{array}$ \\
\hline Point bintang & $\begin{array}{l}\text { Point bintang ada 20 buah diantaranya berwarna merah, kuning, } \\
\text { hijau dan biru. Masing-masing warna ada 5 buah. Point bintang } \\
\text { ini untuk menentukan seberapa banyak anak tersebut } \\
\text { mendapatkan kartu dan melanjutkan permainanna dengan baik. }\end{array}$ \\
\hline
\end{tabular}




\section{Uji Validasi}

Media Reading Domino yang dikembangkan validasi terlebih dahulu oleh ahli media. Validasi media dilaksanakan oleh yang mempunyai latar belakang berpengalaman sesuai dengan media yang dikembangkan. Validasi oleh ahli media bertujuan untuk mendapatkan

informasi, kritik, dan saran agar media Reading Domino yang dikembangkan menjadi produk yang berkualitas secara aspek isi dan tujuan, teknis, dan instruksional. Terdapat 40 pertanyaan dalam lembar validasi ahli media. Ahli media melakukan validasi sebanyak satu kali. Berdasarkan data dapat diketahui skor yang diperoleh sebesar 163 dengan persentase $81,5 \%$, dan rerata skor sebesar 3,7 dengan kategori "sesuai". Perhitungan lebih rinci dapat dilihat pada lampiran hasil perhitungan validasi ahli media pada setiap aspek dapat dilihat pada Tabel 7.

Rerata skor akhir dari validasi ahli media sebesar 3,7 berada pada rerata $3,36<X \leq$ 4,08 atau kategori "sesuai". Berdasarkan hasil tersebut, dapat diketahui bahwa media reading domino yang dikembangkan layak untuk digunakan dan diuji cobakan sebagai alat untuk meningkatkan kosa kata bahasa Inggris pada anak usia 5-6 tahun di sekolah TK B Lab Kristen Satya Wacana Salatiga. Penilaian produk oleh ahli materi berdasarkan rerata skor, disajikan dalam Gambar 2.

Selanjutnya, media Reading Domino yang dikembangkan divalidasi oleh ahli materi. Validasi materi dilaksanakan oleh Dosen Fakultas Bahasa dan Satra (Bahasa Inggris) yang mempunyai latar belakang sesuai dengan materi yang dikembangkan. Validasi oleh ahli materi bertujuan untuk mendapatkan informasi, kritik, dan saran agar media Reading Domino yang dikembangkan menjadi produk yang berkualitas secara aspek isi, tujuan, teknis, dan instruksional. Terdapat 40 pertanyaan dalam lembar validasi ahli materi. Ahli materi melakukan validasi sebanyak satu kali. Berdasarkan data yang diperoleh, dapat diketahui skor yang diperoleh sebesar 182 dengan persentase 91\%, dan rerata skor sebesar 4,20 dengan kategori "sangat sesuai". Hasil perhitungan validasi ahli materi pada setiap aspek dapat dilihat pada tabel berikut.

Rerata skor akhir dari validasi ahli materi sebesar 4,20 dengan rerata $X \leq 4,08$ atau kategori "sangat sesuai". Berdasarkan hasil tersebut, dapat diketahui bahwa media reading domino yang dikembangkan layak untuk digunakan dan diujicobakan sebagai alat untuk meningkatkan kemampuan membaca bahasa Inggris pada anak usia 5-6 tahun di TK B Lab Kristen Satya Wacana Salatiga. Penilaian produk oleh ahli materi berdasarkan rerata skor, disajikan dalam Gambar 3.

Berdasarkan hasil validasi ahli materi dan ahli media, media Reading Domino yang dikembangkan sudah sesuai, namun ada sedikit perbaikan yang perlu dilakukan untuk nantinya dapat dilanjutkan ke tahap selanjudnya. Berikut penjelasan revisi yang berisikan masukan, komentar dan saran dari kedua ahli tersebut. Menurut ahli media ukuran papan permainan harus lebih besar dari sebelumnya sehingga anak dapat bermain dengan baik dan kartu Reading Domino sebaiknya ukurannya sama panjang dan lebar. Sedangkan masukan dari ahli materi menyebutkan media Reading Domino yang menggunakan kartu kosa kata bahasa Inggris, dalam hal kosa kata terlihat dari kartu permainan namun reading tersebut tidak terlalu nampak dalam permainan, yang terlihat justru vocabulary nya. Ahli materi memberi saran untuk judul diubah menjadi "vocabulary domino" karena reading/ kemampuan membaca tidak terlihat, hanya memperlihatkan kosa kata. Namun apabila tidak mengganti judul maka reading harus dimasukkan ke dalam alur bermain seperti menyebutkan nama. Guru juga dapat berpartisipasi atau membantu anak ketika kesulitan dalam membaca bahasa Inggris. Selain itu, pemilihan kata bahasa Inggris harus melekat dengan anak, seperti benda-benda yang ada disekitar anak di dalam kelas. Sehingga anak lebih kenal benda-benda tersebut dengan baik (Khairani, 2016) . 


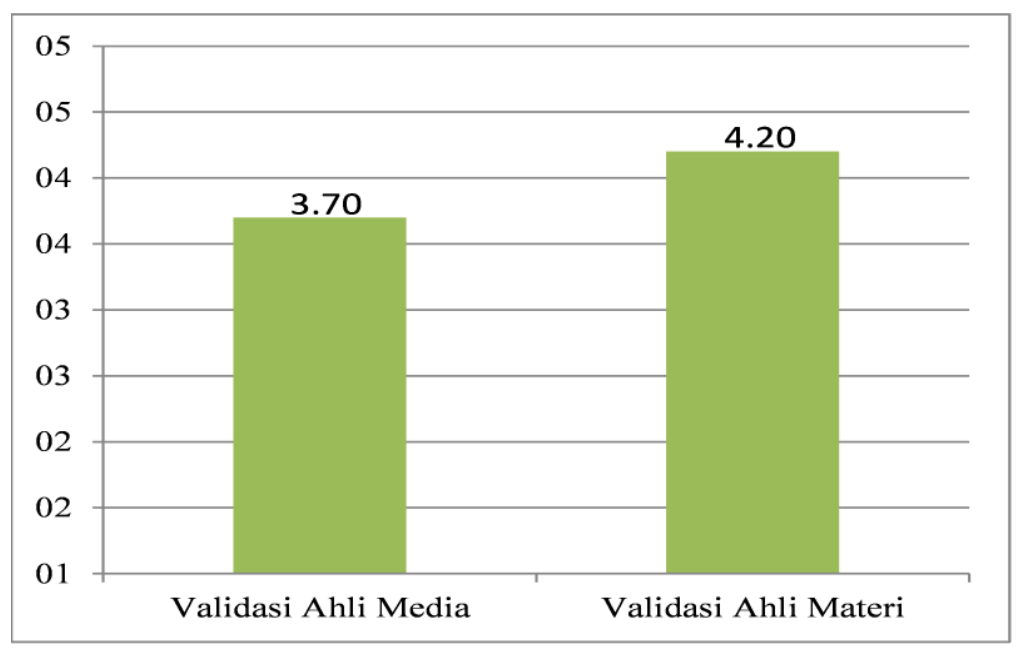

Gambar 3. Diagram Rerata Skor Hasil Validasi Ahli

Tabel . Hasil Validasi Ahli Pada Tiap Aspek

\begin{tabular}{ccc}
\hline \multirow{2}{*}{ Aspek } & \multicolumn{2}{c}{ Skor } \\
\cline { 2 - 3 } & Validasi Ahli Media & Validasi Ahli Materi \\
\hline Kualitas Isi dan Tujuan & 55 & 57 \\
\hline Kualitas Teknis & 83 & 99 \\
\hline Kualitas Instruksional & 25 & 26 \\
\hline Jumlah & 163 & 182 \\
\hline Rentang Rerata Skor & $3,36<X \leq 4,08$ & $X \leq 4,08$ \\
\hline Rerata Skor & 3,7 & 4,20 \\
\hline Kategori Skor & Sesuai & Sangat Sesuai \\
\hline
\end{tabular}

Adapun langkah-langkah permainan kartu Reading Domino yaitu guru mengambil sebuah kartu Reading Domino, kemudian memperlihatkan pada anak. Setelahnya Guru mengucapkan atau membacakan kata yang tertera pada kartu kemudian guru meletakan kartu tersebut di papannya, dan guru mengambil kartu yang sesuai dengan gambar sebelumnya. Saat permainan berlangsung anak diajak mempraktikan permainan kartu Reading Domino secara bersama dalam kelompok dengan langkah-langkah berikut : a) Anak akan dibagi satu kelompok lima orang, b) Setiap anak didalam kelompok akan mendapatkan tiga kartu. (Tersisa satu kartu, diletakan di papan permainan), c) Dalam kelompok akan diberi waktu 5 menit dan bintang 10 untuk menyelesaikan permainan. d) Anak akan bermain secara kooperatif atau bekerjasama. e) Satu kelompok akan diberi 10 point, f) Jika dalam waktu 5 menit anak tidak bisa menyelesaikan permainan akan dikurangi 1 point dan jika anak bisa menyelesaian permainannya maka akan ditambahkan 1 point (Rahma, 2019).

\section{SIMPULAN}

Simpulan dari penelitian dan pengembangan ini, yaitu media Reading Domino yang dihasilkan sesuai untuk diterapkan dalam uji coba sebagai alat untuk belajar membaca bahasa Inggris anak usia 5-6 tahun di TK B Lab Kristen Satya Wacana Salatiga. Berdasarkan hasil uji validitas yang dilakukan ahli meteri dan ahli media dengan rerata skor masingmasing (empat koma dua puluh) dan (tiga koma tujuh puluh) yang berada pada rentang $X$ kurang dari empat koma nol delapan dan tiga koma tiga puluh enam kurang dari $\mathrm{X}$ kurang dari sama dengan empat koma nol delapan yang termasuk dalam kategori "sangat sesuai" dan kategori "sesuai" pada media. 


\section{UCAPAN TERIMA KASIH}

Ucapan terima kasih ini peneliti sampaikan kepada Tuhan Yesus Kristus yang adalah sumber hikmat dan pengetahuan, Papa dan mama, Opa Nus, Oma Mimi, Oma Rose dan seluruh keluarga besar Batmanlusy-Hanorsian, Dosen pembimbing Bapak Mozes Kurniawan, S.Pd, M.Pd dan tim pengajar Program Studi PG PAUD Universitas Kristen Satya Wacana Salatiga, Kepala sekolah serta guru kelas TK Lab Kristen Satya wacana, Temanteman PG PAUD angkatan 2016 dan Sahabat Claudya Stefany Souisa, S.Pd

\section{DAFTAR PUSTAKA}

Elfiadi, E. (2016). Bermain Dan Permainan Bagi Anak Usia Dini. Bermain Dan Permainan Bagi Anak Usia Dini, 7(1), 51-60.

Hadini, N. (2017). Meningkatkan Kemampuan Membaca Anak Usia Dini melalui Kegiatan Permainan Kartu Kata di TK Al-Fauzan Desa Ciharashas Kecamatan Cilaku Kabupaten Cianjur. Jurnal Empowerment.

Hotimah, E. (2010). Penggunaan Media Flashcard Dalam Meningkatkan Kemampuan Siswa Pada Pembelajaran Kosakata Bahasa Inggris Kelas II MI Ar-Rochman Samarang Garut. Jurnal Pendidikan Universitas Garut, 04(01), 10-18. https://journal.uniga.ac.id/index.php/JP/article/download/30/30

KEMEDIKBUD. (2013). Peraturan Menteri Pendidikan dan Kebudayaan Republik Indonesia Nomor 146 Tahun 2014 Tentang Kurikukum 2013 Pendidikan Anak Usia Dini. Journal of Chemical Information and Modeling.

Khairani, A. I. (2016). Pendidikan Bahasa Inggris Untuk Anak Usia Dini. Digilib.Unimed.Ac.Id. http:// digilib.unimed.ac.id/id/eprint/448

Kurniawan, M. (2018). The Analysis of Interlingual and Intralingual Interference in Children's Literature Translation Project. Celt: A Journal of Culture, English Language Teaching E Literature. https://doi.org/10.24167/celt.v18i2.1177

Kurniawan, M. (2020). Testing ICT-based Learning Model 'Creative Reading' as A Trigger of Children's Metalinguistic Awareness in Learning English. JPUD - Jurnal Pendidikan Usia Dini. https://doi.org/10.21009/jpud.141.01

Liyana, A., \& Kurniawan, M. (2019). Speaking Pyramid sebagai Media Pembelajaran Kosa Kata Bahasa Inggris Anak Usia 5-6 Tahun. Jurnal Obsesi : Jurnal Pendidikan Anak Usia Dini, 3(1), 225. https://doi.org/10.31004/obsesi.v3i1.178

Mawarni, A. D., Adi, W., \& Sumaryati, S. (2015). Pengembangan Bahan Ajar Akuntansi Materi Jurnal Penyesuaian Menggunakan Software EXE Sebagai Sarana Siswa Belajar Mandiri Kelas XI IPS SMA Negeri 7 Surakarta Tahun Ajaran 2014 / 2015. Jurnal Tata Arta UNS. https:/ / doi.org/10.1017/CBO9781107415324.004

Mufliharsi, R. (2017). Pemanfaatan Busy Book pada Kosakata Anak Usia Dini di PAUD Swadaya PKK. Jurnal Metamorfosa.

Muzaiyanah, M. (2015). Perkembangan Bahasa Anak Usia Dini. Wardah, 14(1), 25-33.

Pebriana, P. H. (2017). Analisis Kemampuan Berbahasa dan Penanaman Moral pada Anak Usia Dini melalui Metode Mendongeng. Jurnal Obsesi: Jurnal Pendidikan Anak Usia Dini. https://doi.org/10.31004/obsesi.v1i2.34

Rahayu, S. L., \& Fujiati, F. (2018). Penerapan Game Design Document dalam Perancangan Game Edukasi yang Interaktif untuk Menarik Minat Siswa dalam Belajar Bahasa Inggris. Jurnal Teknologi Informasi Dan Ilmu Komputer, 5(3), 341. https:// doi.org/10.25126/jtiik.201853694

Rahma, F. I. (2019). Media pembelajaran ( kajian terhadap Langkah-langkah Pemilihan Media dan Implementasinya dalam Pembelajaran bagi Anak Sekolah Dasar ). Jurnal Studi Islam, 14(2), 87-99.

Rahman, U. (2009). Karakteristik Perkembangan Anak Usia Dini. Lentera Pendidikan: Jurnal Ilmu Tarbiyah Dan Keguruan, 12(1), 46-57. https:/ / doi.org/10.24252/lp.2009v12n1a4 
DOI: $10.31004 /$ obsesi.v5i1.615

Suciati, S. (2018). Peran Orang Tua dalam Pengembangan Bahasa Anak Usia Dini. ThufuLA: Jurnal Inovasi Pendidikan Guru Raudhatul Athfal, 5(2), 358. https://doi.org/10.21043/thufula.v5i2.3480

Sugiyono. (2012). Metode Penelitian Kuantitatif, Kualitatif dan R \& D.Bandung:Alfabeta. Metode Penelitian Kuantitatif, Kualitatif Dan $R \quad \mathcal{E} \quad$ D.Bandung:Alfabeta. https:/ / doi.org/10.1017/CBO9781107415324.004

Sulaiman, U., Ardianti, N., Pendidikan, J., Anak, I., Dini, U., Pendidikan, J., Anak, I., Dini, U., Dini, A. U., \& Pendidikan, S. N. (2019). Tingkat Pencapaian Aspek Perkembangan Anak Usia 5-6 Tahun berdasarkan Standar Nasional Pendidikan Anak Usia Dini. Indonesian Journal of Early Childhood Education.

Widiarina, W. (2016). Animasi Interaktif Pengenalan Bagian Rumah Dalam Bahasa Inggris. Seminar Nasional Ilmu Pengetahuan Dan Teknologi Komputer.

Yumi, M., Atmazaki, A., \& Gani, E. (2019). Performa Kalimat Anak pada Masa Konstruksi Sederhana: Studi Kasus terhadap Anak Usia 4 Tahun. Jurnal Obsesi : Jurnal Pendidikan Anak Usia Dini, 3(1), 191. https:/ / doi.org/10.31004/ obsesi.v3i1.162 